\title{
Connecting Concepts of Cultural Landscape and Historic Urban Landscape: The Politics of Similarity
}

\author{
Ken Taylor \\ College of Arts and Social Sciences, Australian National Univesity, Canberra, Australia \\ Email:k.taylor@anu.edu.au
}

\begin{abstract}
This paper projects the concept of cultural landscapes into the realm of urban conservation in the context of the Historic Urban Landscape (HUL) paradigm. To do this I take an historical overview of how, during the latter half of the 1980s and early 1990s, academic and professional interest in heritage studies started to embrace the cultural landscape construct. This movement continued through the 2000s with increasing links between theory and practice on urban conservation concerns and the concept of cities as cultural landscapes. In this connection the move in 2011 by UNESCO with the Recommendation on the Historic Urban Landscape is particularly notable. Coincidental were two significant movements. First was increasing questioning of heritage as focusing narrowly on the monuments and sites mentality. Second has been the growing appreciation that urban conservation locking onto separate historic towns or specific parts of cities is counter-productive; it ignores towns and cities as holistic entities isolating historic areas virtually as museum pieces separate from the rest of the urban fabric and lacking sustainability. In contrast HUL with its landscape approach is a process' that embraces-city-wide-cultural, natural, tangible and intangible, social, economic, visual and experiential aspects of the physical morphology of the city and the image of the city; it underpins the fundamental concept of urban areas as a series of layers through time that link past, present and future as in the construct of cultural landscape.
\end{abstract}

KEYWORDS cultural landscape, urban conservation, historic urban landscape, heritagisation, charters, values, communities

Received July 18, 2018; accepted September 7, 2018.

'Any landscape is a condition of the spirit.'

-Henri Frédéric Amiel

\section{Introduction: Heritagisation Process and Shifting Discourses}

A brief side journey into changes that have taken place in thinking on heritage and what it means and the role of cultural landscape thinking is appropriate to set a context for this paper. When you want to know where you are going, it is useful contextually to know where the journey started.

During the late 1980s onwards criticism of the global frameworks for protecting cultural heritage that had evolved after the promulgation of the World Heritage Convention in 1972 started to be voiced. These frameworks were underpinned by methodical approaches to identification and assessment of heritage resources, analysis of significance, and evaluation of proposals that led to an internationally accepted modus operandi accompanied by adoption of various charters. The outcome saw a modern bureaucratic system evolve where heritage resources are itemised through categories and entered in registers and lists. While we need to apply such tools anchored in a systematic and demonstrable way of working, they, and associated charters, have in the past shown their Western cultural origins and Western values. An underlying concern is how far do such universal approaches based on Western methodologies and thinking adequately address regional cultural values and differences across the world (Taylor 2014)?

A central question, therefore, is have we progressed, and if so to what extent, from critiques that methods of working, tools and in particular associated charters did show their Western cultural origins? And in particular European values as has repeatedly been claimed. My answer to this 
question is that undoubtedly progress has been made, and has been seen to be made not only through scholarly and academic discourse but through changes in thinking in the global conservation profession and global agencies. Critical to changes has been the birth of a different value system with attention focused on such issues as cultural landscapes, living history and heritage, intangible values, and community involvement. It is a system that has grasped the fundamental importance of understanding the central role of cultural context in the heritage conservation process. In this connection Winter $(2014,125)$ addresses shifts in approaches to heritage conservation and the politics of difference, noting that 'from within academia and the heritage conservation profession the calls for approaches more sensitive and responsive to the cultural context of the site or country in question have become increasingly loud.' I contend that progressive professional changes have occurred, and notable ones at that, and we are seeing in effect the emergence of the politics of similarity. Table 1 outlines my view of notable professional milestones in the chronology of, and actions in, development of the heritage process, including various charters and declarations, in the late modern/postmodern period since World War II, but particularly from circa 1990 onwards (Table 1).

Contrary to the scepticism of some scholars that the international bureaucracies and agencies, in particular UNESCO and ICOMOS, are immune to changes in thinking and broadening of cultural heritage theory and practice (Askew 2010; Logan 2010), is the counter argument that it is a view not supported by evidence of shifts that have occurred (Table 1) in the 45 years since 1972 (see also Taylor 2017). Criticisms of the agencies revolve, inter alia, around what is seen as 'a one size fits all' globalising approach that stifles regional cultural differences. Contrary to such a view is that changes that have occurred are indicative of 'UNESCO's progressive accommodation of heritage diversity' (Askew 2010, 28) and demands to expand its thinking and practice. Askew $(2010,19)$ further cogently argues that UNESCO has expanded its programmes to mitigate the destructive effects of capitalism's globalisation of cultural industries, and that its key texts can be seen as beneficent globalisation by its advocacy for world-wide protection of cultures and their valued tangible and intangible past. Harrison similarly reflects how there has been a shift 'to accommodate an increasingly large number of objects, places, and perhaps most importantly, practices, and the landscapes in which these occur' (Harrison 2013, 115). Coincidental has been the broadening of concern with culture and the intangible rather than focusing primarily on things. In the shift away from a concentration on monuments and sites, heritage now embraces:

Precincts, historic urban centres, whole towns and villages, cultural landscapes, and historic urban landscapes, associative values and intangible heritagethe talents embodied in people, such as artistic skills in dance, music and painting, or skills in language, or craft and construction skills (Logan 2010, 38).

\section{Consciousness of the Human Side of Landscape}

The period from the mid-1980s to the early 1990s, alongside critical thinking on the heritagisation process, saw the emergence of the topic of cultural landscapes as potentially one 'of great interest to the conservation community' (Jacques 1995, 91), heralding an opportunity to rethink concepts of heritage. It also saw the introduction by the World Heritage Committee of the three categories of cultural landscapes in 1992 (Cameron and Rössler, 2013). The touchstone for the landscape movement was the scholarly work and writing of cultural geographers who had for decades understood the pivotal role of landscape in people's sense of place, place meaning and values that are regarded as central to a conservation ethic. Jacques $(1995,91)$ in his paper 'The Rise of Cultural Landscapes' articulated that critical to the rise was 'the concept of value that cultural landscapes brought with them'. In prophetic mode Gerald Patten $(1991,1)$ in introducing an edition of Cultural Resource Management (CRM) for the United States National Park Service referred to 'Cultural Landscapes: The Intent and Tenor of the Times' and 'the growing urgency of recognizing and protecting our legacy of cultural landscapes for their historical value and for their contribution to society today? In the sense of 'tenor' as a movement or activity, cultural landscapes-with their inseparable meanings and values-have become a dominant philosophical foundational element for the way we think and act in the heritage management process.

Over the last 35 years or so there has emerged, therefore, the idea of historic cultural landscapes being worthy of heritage conservation action. It is a movement that embraces an extraordinary array of landscapes from everyday landscapes to the international level of World Heritage landscapes. This rethinking is linked to criticism of a heritage focus on monuments and famous sites. 
Table 1 Chronology of steps and actions in development of the heritage process (Source: the author).

\begin{tabular}{|c|c|}
\hline Year & Steps and Actions \\
\hline 1945 & The United Nations [UN] was formed. \\
\hline $\begin{array}{l}\text { November } \\
1945\end{array}$ & Creation of the United Nations Educational, Scientific and Cultural Organisation [UNESCO]. \\
\hline $\begin{array}{l}\text { November } \\
1946\end{array}$ & $\begin{array}{l}\text { The Constitution of UNESCO [November 1946] mandates the Organisation to ensure the conservation and protection of the } \\
\text { world's inheritance of books, works of art and monuments of history and science (UNESCO 2007). Here was established the } \\
\text { firming of globalised thinking on cultural heritage protection in the modernist tradition of 'ideas and practices that could be } \\
\text { applied around the world regardless of differences in local cultures' (Logan 2010). }\end{array}$ \\
\hline 1959 & $\begin{array}{l}\text { In the early UNESCO years, various missions were organised to advise Member States on the conservation of heritage sites. } \\
\text { Later these developed into international campaigns, of which the first was launched in } 1959 \text { on the Temples of Abu Simbel, } \\
\text { Egypt, threatened by the construction of the Aswan Dam. }\end{array}$ \\
\hline 1964 & $\begin{array}{l}\text { UNESCO also collaborated in the organisation of meetings of experts in the preservation of heritage resources. These included } \\
\text { a conference on the preservation of monuments held in Venice in 1964, which adopted the International Charter for the } \\
\text { Conservation and Restoration of Monuments and Sites (The Venice Charter). }\end{array}$ \\
\hline 1972 & $\begin{array}{l}\text { In } 1972 \text { at a UN conference on the human environment in Stockholm, it was recommended that a UNESCO convention on } \\
\text { World Heritage should be adopted, resulting in The Convention Concerning the Protection of the World Cultural and Natural } \\
\text { Heritage ( } 16 \text { November 1972). Generally known as The World Heritage Convention, it has achieved a great deal during its } \\
\text { existence. 'Today, it is among the foremost international tools of conservation, and certainly among the best known.' (Bandarin } \\
2007,18 \text { ) }\end{array}$ \\
\hline & $\begin{array}{l}\text { UNESCO was instrumental in setting up key international organisations-ICOMOS, ICCROM, and IUCN-that became } \\
\text { official advisory bodies to the World Heritage Centre. } \\
\text { International Council on Monuments and Sites (ICOMOS), a non-governmental organisation with headquarters in Paris, was } \\
\text { established in 1965. It is dedicated to the conservation of the world's historic monuments and sites, and provides a forum for } \\
\text { professional dialogue and a vehicle for the collection, evaluation and dissemination of information on conservation principles, } \\
\text { techniques and policies. It also is an Advisory Body to the World Heritage Committee as designated in the Convention for the } \\
\text { Protection of the World Cultural and Natural Heritage (World Heritage Convention). } \\
\text { International Centre for the Study of the Preservation and Restoration of Cultural Property (ICCROM) based in Rome was } \\
\text { established in } 1956 \text { by UNESCO. It has a worldwide mandate to promote the conservation of all types of cultural heritage, } \\
\text { movable and immovable, with the aim of improving the quality of conservation practices and raising awareness about the } \\
\text { importance of preserving cultural heritage through training, cooperation, research, information and awareness. } \\
\text { International Union for Conservation of Nature and Natural Resources (IUCN) based in Gland, Switzerland, was established } \\
\text { in } 1948 \text { with the original denomination of International Union for the Protection of Nature, which was changed to the current } \\
\text { IUCN in } 1956 \text {. It is committed to the conservation of the integrity and diversity of nature and aims to ensure the sustainability } \\
\text { of the use of natural resources worldwide. It is responsible for the production of international agreements on nature } \\
\text { conservation and acts as an advisory body to the World Heritage Convention. }\end{array}$ \\
\hline 1976 & UNESCO, Recommendation concerning the Safeguarding and Contemporary Role of Historic Areas (Nairobi Recommendation). \\
\hline 1979 & Australia ICOMOS Charter for Conservation of Places of Cultural Significance (The Burra Charter), updated in 1999 and 2013. \\
\hline 1987 & ICOMOS Charter for the Conservation of Historic Towns (Washington Charter). \\
\hline \multirow[t]{3}{*}{1992} & $\begin{array}{l}\text { The World Heritage Centre was established and is the focal point and coordinator within UNESCO for all matters related to } \\
\text { World Heritage as its secretariat including: management of the Convention; organising annual World Heritage Committee } \\
\text { meetings; providing advice to States Parties in the preparation of nominations; coordinating the reporting on the condition } \\
\text { of properties and the emergency action undertaken when a property is listed in danger. The Centre also organises technical } \\
\text { seminars and workshops; updates the World Heritage List and database; develops teaching materials to raise awareness among } \\
\text { young people of the need for heritage preservation; and keeps the public informed of World Heritage issues. }\end{array}$ \\
\hline & $\begin{array}{l}\text { UNESCO Experts Meeting La Petite Pierre proposes categories for World Heritage recognition and revisions to WH } \\
\text { Operational Guidelines. }\end{array}$ \\
\hline & $\begin{array}{l}\text { UNESCO World Heritage Centre recommends three categories of Cultural Landscapes for World Heritage recognition by WH } \\
\text { Committee. }\end{array}$ \\
\hline \multirow{2}{*}{1993} & Cultural Landscape Colloquium Montreal. \\
\hline & UNESCO Experts Meeting, Templin, Germany. \\
\hline
\end{tabular}


Table 1 (continued).

\begin{tabular}{|c|c|}
\hline Year & Steps and Actions \\
\hline \multirow[b]{2}{*}{1994} & ICOMOS, The Nara Document on Authenticity. \\
\hline & $\begin{array}{l}\text { The World Heritage Committee (WHC) launched the Global Strategy for a Representative, Balanced and Credible World } \\
\text { Heritage List (http://whc.unesco.org/en/globalstrategy). With the aim ensuring that the List reflects the world's cultural and } \\
\text { natural diversity of outstanding universal value. The WHC wanted to broaden the definition of World Heritage to reflect better } \\
\text { the full spectrum of the world's cultural and natural treasures and to provide a comprehensive framework and operational } \\
\text { methodology for implementing the World Heritage Convention. It resulted from a global study carried out by ICOMOS } \\
\text { from } 1987 \text { to } 1993 \text { revealed that Europe, historic towns and religious monuments, Christianity, historical periods and 'elitist' } \\
\text { architecture (in relation to vernacular) were all over-represented on the World Heritage List; whereas, all living cultures, and } \\
\text { especially 'traditional cultures', were underrepresented. }\end{array}$ \\
\hline 1996 & Cities of Asia, UNESCO, http://whc.unesco.org/en/activities/498/ \\
\hline \multirow[b]{2}{*}{2000} & ASEAN Declaration On Cultural Heritage, Bangkok, Thailand, 24-25 July 2000. \\
\hline & $\begin{array}{l}\text { Early 2000s to present: mounting critical heritage studies debate on what is heritage and importance of 'culture' in cultural } \\
\text { heritage; questioning of universality of heritage values particularly in the WH Convention; intangible cultural heritage; } \\
\text { criticism of a primary locus of attention on famous monuments and sites. }\end{array}$ \\
\hline \multirow{2}{*}{2002} & UNESCO Budapest Declaration on World Heritage addressing intangible cultural heritage. \\
\hline & ICOMOS China Principles for Conservation of Heritage Sites in China. \\
\hline \multirow{2}{*}{2003} & UNESCO World Heritage Centre, Convention for the Safeguarding of the Intangible Cultural Heritage. \\
\hline & ICOMOS The Hoi An Declaration on Conservation of Historic Districts of Asia. \\
\hline 2004 & UNESCO World Heritage Paper 13, 'Linking Universal and Local Values'. \\
\hline \multirow[t]{2}{*}{2005} & $\begin{array}{l}\text { The World Heritage List. Filling the Gaps: An Action Plan for the Future (ICOMOS 2005). The plan was intended as a } \\
\text { contribution to the further development of the Global Strategy for a credible, representative and balanced World Heritage List. }\end{array}$ \\
\hline & UNESCO, Convention on the Protection and Promotion of the Diversity of Cultural Expressions. \\
\hline 2006 & UNESCO World Heritage Paper, 'World Heritage and Buffer Zones'. \\
\hline \multirow{2}{*}{2007} & World Heritage Challenges for the Millennium 2007 (UNESCO World Heritage Centre). \\
\hline & ICOMOS Declaration on Heritage and Metropolis Asia and the Pacific. \\
\hline \multirow{2}{*}{2009} & UNESCO Bangkok, Hoi An Protocols for Best Conservation Practice in Asia. \\
\hline & UNESCO World Heritage Papers 26 'World Heritage Cultural Landscapes. A Handbook for Conservation and Management'. \\
\hline 2011 & UNESCO Recommendation on the Historic Urban Landscape. \\
\hline 2012 & UNESCO World Heritage Papers 31 ‘Community Development through World Heritage’. \\
\hline \multirow{2}{*}{2013} & UNESCO New Life for Historic Cities: the Historic Urban Landscape Approach Explained. \\
\hline & Publication: Managing World Cultural Heritage. \\
\hline 2014 & $\begin{array}{l}\text { UNESCO World Heritage Papers } 40 \text { 'Engaging Local Communities in Stewardship of World Heritage A Methodology based } \\
\text { on the Compact Experience'. }\end{array}$ \\
\hline 2016 & $\begin{array}{l}\text { UNESCO et al., The HUL Guidebook. Managing Heritage in Dynamic and Constantly Changing Urban Environments. A } \\
\text { Practical Guide to UNESCO's Recommendation on the Historic Urban Landscape. }\end{array}$ \\
\hline
\end{tabular}

Inextricably linked to a cultural concept of landscape is the understanding that one of our deepest needs is for a sense of identity and belonging and that a common denominator in this is human attachment to landscape and how we find identity in landscape and place. Cultural landscape study has also been coincidental with a widening interest in the public history movement and everyday landscapes. It underpins the notion that landscapes reflecting everyday ways of life, the ideologies that compel people to create places, and the sequence or rhythm of life over time tell the story of people, events and places through time, offering a sense of continuity: a sense of the stream of time. They also offer the context for broader concepts and understandings of cultural heritage than monuments and sites. It fits with Cosgrove's (1984) dictum that landscape is not what we see, but a way of seeing. In this sense landscape is not simply or overwhelmingly a product, it is a process in which humans create landscapes-cultural landscapes - where 'our human landscape is our unwitting biography, reflecting our tastes, our values, our 
aspirations, and even our fears in tangible visible form'. (Lewis 1979, 12) ${ }^{2}$. Landscape therefore is not static, it reflects changing human ideologies over time (Biger 1992) in culturally diverse communities.

Notably — and not by accident I might add - the concept of landscape as process dovetails nicely with the widening understanding of heritage as process (Harvey 2001; Howard 2003). In neat alignment these processes simultaneously embrace concepts of 'living history' and 'living heritage' to encompass the full spectrum of people's sense of place, traditional knowledge and its transmission, cultural production including equity and access, creativity and innovation, and the safeguarding of natural resources and cultural traditions that provide the foundations of local livelihoods in urban as well as rural settings as expressed in the urban-rural linkages of the UN Habitat III-New Urban Agenda. Further, the concept of living heritage as a resource for local communitybased sustainable development offers a foundation for an association of cultural sustainability with heritage management action. Inherent in this concept and the Historic Urban Landscape (HUL) paradigm is that change is a constant and we have to address the notion of what are acceptable levels of change.

In addition to recognising the profundity of the concepts of living history and living heritage as a prime resource for local community-based sustainable development, they have become a lens through which cultural heritage management is increasingly perceived. The shift that has occurred in thinking on living history/living heritage is part of the re-orientation away from caring solely for the physical fabric of heritage structures inherent in the 'conventional' (Wijesuriya et al. 2013) cultural heritage management approach towards recognising the significance of intangible cultural heritage and associated values of living communities, as well as the needs and wishes of living communities who are the custodians of this heritage. In this connection the Nara Document on Authenticity (ICOMOS 1994) is particularly relevant in the reorientation away from concentration on fabric to intangible aspects of authenticity and human values and understanding of regional differences. Putting them centrestage, the thinking goes, ensures a more engaged, better informed and locally rooted conservation management process, which is more culturally sustainable. Poulios (2014, 28; see also Poulios 2015) expresses this in his three key principles that determine a 'living heritage approach':

1. Recognising local communities as the true long-term custodians of their heritage sites;
2. Empowering communities in the conservation and management process, and benefiting from their traditional knowledge, management systems and maintenance practices; and

3. Linking conservation to the sustainable development of the communities, by developing a process to manage change and by making heritage relevant to the needs of the contemporary communities.

Embedded in fundamental concepts of landscape is that of linking people, events and places through time which has led to an increasing appreciation of intangible values that inhere in places because of the association of ideas between people and place. 'In this way we can appreciate that all cultural landscapes have associative values.' (Taylor 2015, 189) Julian Smith $(2010,46)$ eloquently expresses this:

... it is useful to think of cultural landscapes as ideas embedded in a place, and to consider the recording of cultural landscapes as an exercise in cognitive mapping rather than physical mapping. The challenge of this approach is that a cultural landscape cannot be observed, it must be experienced. And it must be experienced within the cultural framework of those who have created and sustained it ... some would argue that this kind of cultural landscape is an associative cultural landscape.

It is useful at this stage to look at a definition of cultural landscape. Here I refer to a paper by Peter Fowler 'Cultural Landscape: Dreadful Phrase, Great Concept' in which Fowler (2001) includes a number of definitions. The definition I quote below, and why it is quoted, is because it is succinct. Like Fowler I find it theoretically and professionally workable: the last sentence expressing the very essence of what we mean by 'cultural landscapes' with 'a brevity beguiling its profundity' (Fowler 2001, 67):

Cultural landscapes reflect the interactions between people and their natural environment over space and time. Nature, in this context, is the counterpart to human society; both are dynamic forces, shaping the landscapes ... A cultural landscape is a complex phenomenon with a tangible and intangible identity. The intangible component arises from ideas and interactions which have an impact on the perceptions and shaping of a landscape, such as sacred beliefs closely linked to the landscape and the way it has been perceived over time. Cultural landscapes mirror the cultures which created them [my italics] (Plachter and Rössler in von Droste et al. 1995, 15). 


\section{Cultural Landscapes and Urbanisation}

The cultural landscape concept underscores an awareness that heritage places are not isolated islands and that there is interdependence between people, their social structures and ecosystems and landscape conservation. Additionally, increasing attention is now being focused on urban cultural landscapes including under the HUL paradigm. This is an approach to historic urban conservation which sees towns and cities as consisting of layers through time as in the cultural landscape concept. It marks a shift away from the preoccupation with the historic city as visual object with a focus on famous buildings or groups of buildings divorced from their cultural setting to an interest in the historic environment as a space for ritual and human experience.

Given that a major rationale behind this paper is interrogating changes that have occurred and continue in the broadening understanding of the cultural heritage process, it is appropriate to consider cultural heritage conservation theory and practice through the lens of the march globally into urbanisation. In this regard the question posed in the following commentary is apposite: Current urbanisation policies often ignore the importance of cultural heritage preservation and promotion and the great potential of creativity in addressing social, environmental and economic urbanisation challenges. How does culture weigh in addressing urbanisation challenges today?

Today, for the first time in human history, more than half of the world's population lives in cities. According to UN-Habitat, if the current trends continue, within two decades, five billion people will live in cities, a majority of them in the Global South. Coincidentally, within the field of cultural heritage conservation, increasing international interest and attention over the past two decades has been focused on urban areas. This is timely because pressure for economic development and the prioritising of engagement with the global economy have accompanied rapid urbanisation. In many societies, and not least in Asia, pressures for economic development have privileged modernisation efforts leading to the loss of traditional communities. Accompanying this has been a concentration in the field of urban conservation on famous buildings and monuments rather than seeing cities as communities of people with values and belief systems that are reflected in the city's overall setting: its cultural landscape. As a result, an alternative way of seeing cities-the HUL paradigm-has evolved and it is discourse around this paradigm that I address in the following part of the paper.

\section{The Historic Urban Landscape (HUL)}

Embedded in HUL is the recognition of the layering of significances and values in historic cities, deposited over time by different communities under different contexts (Bandarin and van Oers 2012). It is an approach that dovetails with the cultural landscape concept of layers through time replete with social meanings. Cities may, therefore, be categorised as a type of cultural landscape (Taylor 2015). The cultural landscape paradigm can be seen to offer a trajectory of thinking relevant to the historic urban setting, not least because it connects with the notion of landscape study as a form of social history reflective of human values. The significance of the cultural landscape concept in the urban sphere is that it allows us to see and understand the approach to urban conservation concentrating on individual buildings as 'devoid of the socio-spatial context [that] contributes to a deterioration of the urban physical fabric' (Punekar 2006, 110). Greffe $(2010,3)$ reinforces this urban landscape way of thinking as contrary to seeing the city as a closed view of architectural wonders of historic cities, but rather seeing the 'postmodern city where we are looking for feelings and emotions. The landscape then becomes an experience'. In contrast do we really want the concept of an historic urban zone to rely substantively on the model of 'the deliberately assembled museum-town [and] vernacular museumification of existing towns and districts' critiqued by Ashworth and Graham $(2012,591)$ ? Here I am reminded of World Heritage listed Old Quebec which effectively shuts down after the shops close.

For me as a cultural geographer and planner the move into landscape linked HUL is welcome, not least in that it builds on the pioneering work of distinguished geographers in urban studies, including Donald Meinig, Wilbur Zilenski, Fred Kniffen, John B. Jackson, Peirce Lewis, Arthur E. Smailes, and Edward Relph. Central to such a paradigm shift emphasising the need for a landscape approach is the inalienable role of human values. Continuing this line of thought Punekar $(2006,111)$ makes a strong case for adopting a cultural landscape approach:

A cultural landscape approach enables diverse communities to be seen as part of that landscape. That is, cultural, historical, and political conditions affecting contemporary communities are part of the process of human engagement with the place. The cultural landscape approach can be a means of reuniting fragmented approaches to valuing and constructing the environments we inhabit, a means of overcoming distinctions 
between historic environment and new development, nature and culture, built heritage and context.

To this I would add that the cultural landscape approach also acknowledges that change is an inevitable factor and has to be addressed.

Changes in line with expanded thinking generally on heritage conservation in the later 1980s started to be seen in urban conservation. Reflective, for example, of this are the 1987 ICOMOS Charter for the Conservation of Historic Towns (Washington Charter) and the 2000 ICOMOS Hoi An Declaration on Conservation of Historic Districts of Asia. The Washington Charter notes in particular (Article 3 ) that 'the participation and the involvement of the residents are essential for the success of the conservation programme'. Here came an understanding of the significance of built urban heritage as the places where people live their everyday lives, where social values and a sense of place exist. In this connection the perceptive observation by J. B. Jackson $(1994,151)$ is apposite:

Most of us, I suspect, without giving much thought to the matter, would say that a sense of place, a sense of being at home in a town or city, grows as we become accustomed to it and learn to know its peculiarities. It is my belief that a sense of place is something that we ourselves create in the course of time. It is the result of habit or custom.

The shift to an holistic, contextual view of urban heritage to include the idea of landscape as setting for people's lives-and within this the idea of sense of placeis seen in the initiative of two further documents: Xian Declaration on the Conservation of the Setting of Heritage Structures, Sites and Areas (ICOMOS 2005) which throughout refers to the holistic concept of landscape as setting for sustainable local communities (including urban settings) and the Seoul Declaration on Heritage and Metropolis in Asia and the Pacific (ICOMOS 2007). Notably the Declaration, in relation to a wider understanding of heritage, proposes (ICOMOS 2007, 6) that

These heritage sites contribute to the life and memory of the metropolitan areas by the diversity of their uses. ... Along with geographical features and the living social ecosystem, cultural heritage contributes strongly to the personality and character of the metropolis. It is a source of a truly sustainable development of the metropolitan areas in Asia and the Pacific in achieving their strategic and economic roles.
Whilst the Seoul Declaration relates specifically to an Asian context, its five major recommendations are highly relevant to consideration of sustainable urban conservation needs globally:

1. Cultural heritage should be recognised as a diverse and non-renewable asset, essential to the sustainable and human development of metropolitan areas in Asia and the Pacific.

2. Conservation of cultural heritage should be integral to the development of the city, including policies, programs and projects, from their planning to their approval, implementation and updating.

3. Conservation is comprised of the on-going identification, evaluation, protection and management of cultural heritage supported by the necessary human, scientific and financial resources.

4. Conservation of cultural heritage requires the development and implementation of adapted tools founded on recognised best practice and local conditions and traditions.

5. Conservation in metropolitan areas requires information, involvement and cooperation among the public, private, academic, and non-government sectors as well as citizens and international organizations.

The concept of the Historic Urban Landscape (HUL) is a major initiative by UNESCO in the field of conservation of urban areas associated with change that is taking place in the world's cities. It was first set out at a UNESCO conference in Vienna ${ }^{4}$, May 2005, and advocated in the Vienna Memorandum on World Heritage and Contemporary Architecture-Managing the Historic Urban Landscape. It followed concern by the World Heritage Committee about impacts of modern developments on historic urban areas and compatibility with the protection of their heritage values. This was particularly so with its proposition of the Historic Urban Landscape notion as a tool to reinterpret the values of urban heritage, and its indication of the need to identify new approaches and new tools for urban conservation. The Vienna Memorandum was pivotal to the Declaration on the Conservation of Historic Urban Landscapes by the General Assembly of UNESCO in October $2005^{5}$. Van Oers $(2010,8)$ noted that:

The Vienna Memorandum is not a Charter, nor was it intended as a finalised document that could guide urban development and conservation for decades to come-it represented a consensus product, established with the involvement of various professional entities, to serve as a catalyst for opening up the debate ... It 
is a transitional document which hints at a vision of human ecology and signals a change towards sustainable development and a broader concept of urban space suggested as 'landscape' - not so much the designed and evolved landscapes that are familiar to most conservation specialists, but rather associative landscapes or 'landscapes of the imagination" .

In this context its thinking and intention therefore paved the way for reviewing debate on new approaches to urban conservation. The establishment in the Vienna Memorandum of the HUL concept was, in effect, a highwater mark for the heritage conservation field. It marked the start of a shift away from the preoccupation with the historic city as visual object to an interest in the historic environment as a space for ritual and human experience. Van Oers summarises this shift towards the HUL paradigm in the following definition (Van Oers 2010, 14) ${ }^{7}$ :

Historic Urban Landscape is a mindset, an understanding of the city, or parts of the city, as an outcome of natural, cultural and socio-economic processes that construct it spatially, temporally, and experientially. It is as much about buildings and spaces, as about rituals and values that people bring into the city. This concept encompasses layers of symbolic significance, intangible heritage, perception of values, and interconnections between the composite elements of the historic urban landscape, as well as local knowledge including building practices and management of natural resources. Its usefulness resides in the notion that it incorporates a capacity for change.

The culmination of thinking on new international approaches to urban conservation came in 2011 with the UNESCO Recommendation on Historic Urban Landscape (UNESCO 2011). This instrument recognised the layering of significances and values in historic cities deposited over time by different communities under different contexts. It is an idea that is succinctly summarised by the comment in UNESCO publication New life for historic cities (UNESCO 2013, 5):

Urban heritage is of vital importance for our citiesnow and in the future. Tangible and intangible urban heritage are sources of social cohesion, factors of diversity and drivers of creativity, innovation and urban regeneration.

The idea of layering therefore strikes a chord with, and relates closely to, the cultural landscape concept. The
Recommendation recognises the challenges of contemporary urbanisation, as well as the importance of cities as engines of growth and centres of innovation and creativity that provide opportunities for employment and education. The Recommendation identified urban heritage, including its tangible and intangible components in their natural context, as a key resource in enhancing the liveability of urban areas and fostering economic development as well as social cohesion. As a tool the Recommendation on HUL is not, and was never intended to be, a separate heritage category; rather it is an approach to management of change in urban settings where considerations of heritage and culture are integral to the planning process.

\section{Communities and Urban Conservation: Some Asian Examples}

\section{Bangkok}

The rapid changes taking place throughout cities globally all too often amount to an attack on urban diversity and vibrant streetscapes that reflect interesting and traditional social patterns. This phenomenon is particularly relevant in Asian cities where so much of the traditional life is experienced on the streets and the communities associated with urban cultural landscapes of small provincial towns and also distinctive precincts in cities. Representing a vibrancy of 'living history and heritage [which] exist in [their] cultural landscapes, traditions and representations' (Taylor 2013a, 193), such places are under threat as Worrasit Tantinipankul $(2014,114)$ in relation to Thailand thought provokingly posits:

Historical urban communities in provincial towns across Thailand are facing rapid demolition as a result of urban development. Comprised of simple wooden shop houses reflecting humble architectural craftsmanship, the character of these historical provincial towns is one which reflects unique patterns of urban livelihood and culture in Thailand. And yet, this provincial urban cultural landscape does not figure into the official Thai conception of 'architectural heritage'.

Tantinipankul further reflects that images of Thai heritage-and also a major focus of tourism-have since the 1920 s centred on famous glittering monuments and sites: primary cultural heritage attractions such as World Heritage properties and those on National Heritage registers that feature in countless glossy magazines, travel brochures, promotional tourism literature and will draw tourists and visitors in their own right. They are representative 


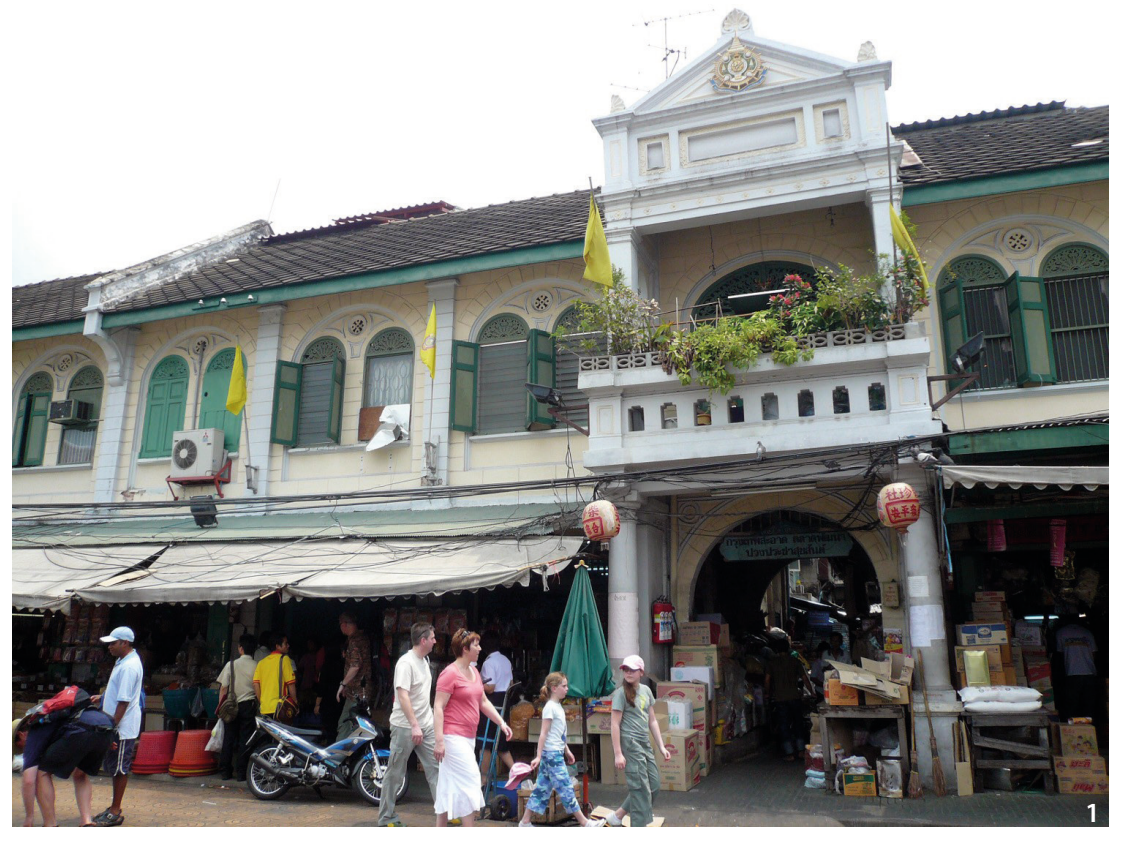

Figure 1 Tha Tien before restoration (Source: T. Sirisrisak). of the conventional approach to heritage conservation and management contrasting with the values led approach focusing on involving communities, cultural and participatory mapping to understand people's values, intangible connections to places and sense of identity. In contrast to primary attractions are what can be termed secondary attractions. 'Secondary attractions will appeal to tourists once they are already at a destination and are examining options for best use of their time and so become a more discretionary choice.' (Du Cros 2002, 319)

Secondary attractions are the places we pass through on the way to primary attractions or places adjacent to primary attractions as in the case of Tha Tien district of Bangkok near the Royal Palace and Wat Pho (Pimonsathean 2006; Sirisrisak 2009). It is a lively and vibrant vernacular streetscape popular with tourists and local people redolent with interesting and traditional social patterns. Tha Tien is an old community on a significant part of Rattanakosin Island flanking the Chao Praya River and adjacent to major heritage and tourist attractions including the Grand Palace, Temple of the Emerald Buddha (Wat Phra Kaew), and Temple of the Reclining Buddha (Wat Pho). Its general history dates to the $17^{\text {th }}$ century when King Rama I established the new capital of Siam at Rattanakosin. The Tha Tien shophouses were built in the $19^{\text {th }}$ century under the direction of King Rama V as rental housing and shops for low income people (Figure 1). 'Due to its strategic location and significance Tha Tien was subject to an ideal "beautification concept" in the Rattanakosin conservation and development master plan' (Pimonsathean 2006, 5) of
1997 under the direction of the Bangkok Metropolitan Administration (BMA) (Figure 2). Of the 490 shophouses more than 400 were to be demolished, leaving only 61 to be restored and reused for tourist service or retailing. The major part of the site was to be given over to open space parkland supposedly for tourists (Figure 3 ). The fact that tourists visit such areas because of the vitality and living history character soredolent of cities like Bangkok seems to have escaped attention of the planners, as did the fact that 'The provision of open space after the building demolition will destroy the historic fabric of Rattanakosin because the long established community will no longer exist.' (Pimonsathean 2006, 6) An alternative planning approach commenced in 1998 with a distinct series of steps:

- Step 1: Scan the environment

- Step 2: Household survey

- Step 3: Architectural survey and documentation

- Step 4: Integrative analysis

- Step 5: Hearings and meetings: In this step, all the findings from the analysis have been presented to the community members and the BMA officials. The presentation and discussion were organised in many forms to facilitate the different profiles of the beneficiary groups such as government officials, affected residents, community development committee as well as local politicians. After a series of presentation, discussion and consultation, an alternative conservation plan for Tha Tien was formulated and presented in a community hearing (Figure 4). The hearing was organised with the community. 

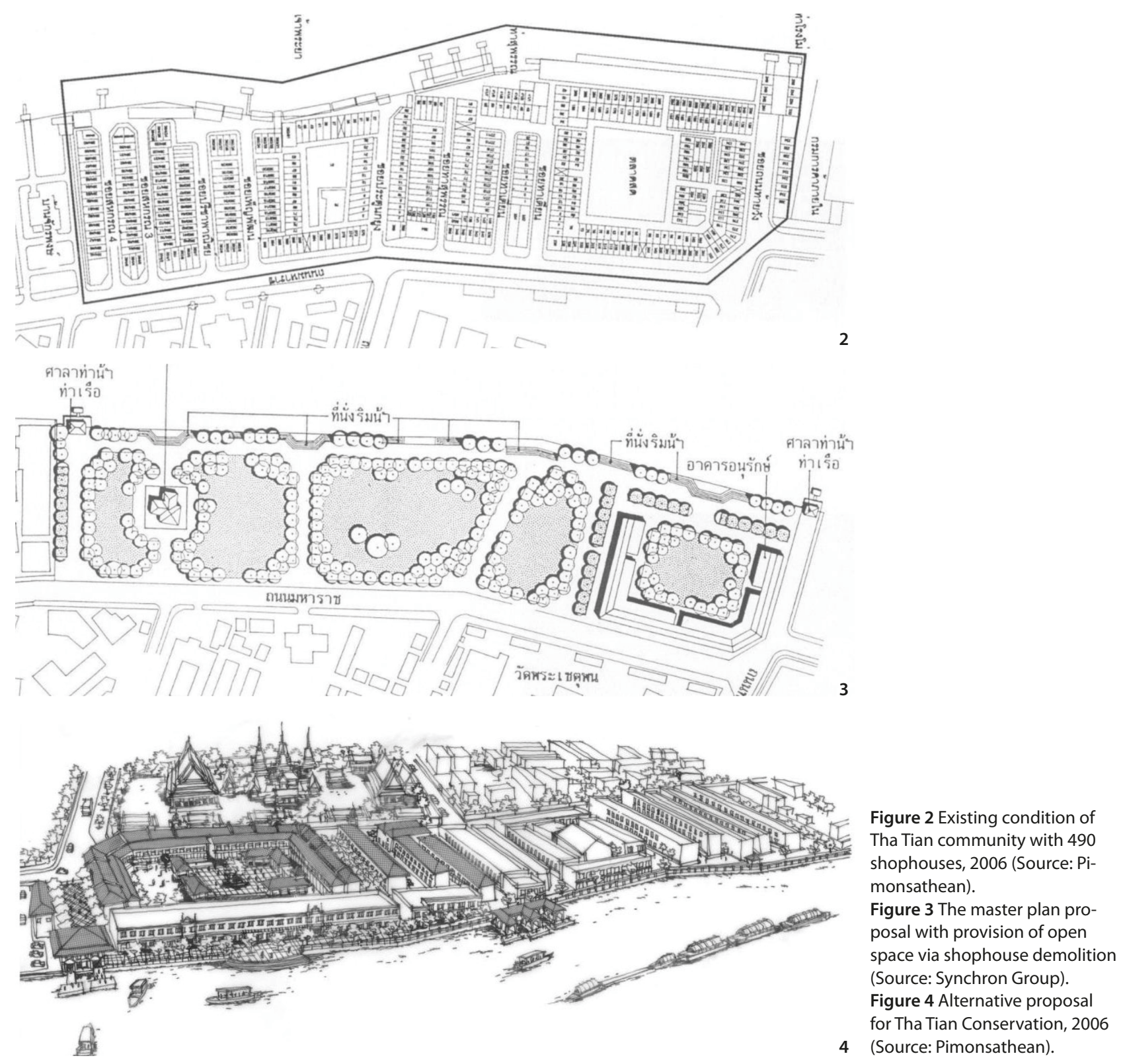

- Step 6: Alternative proposal including a series of hearings, discussions and consultations have made it possible to propose an alternative conservation plan which has four features as follows: the restoration of 319 units of shophouse instead of keeping only 61 units as defined in master plan.

- Step 7: public presentation.

The restoration of 319 shophouses (Figures 4, Figure 5 ) has caused some social dislocation with not all original residents able to return. The type of goods on sale has to some extent changed with, for example, coffee shops opened catering for tourists. Nevertheless, the exercise of looking at an alternative-an acceptable level of changeto demolition with community input and some sense of continuity maintained has resulted in an outcome that reflects history. It also reflects different community urban heritage values to those of the government established national conservation committee.

Another similar example in Bangkok is Talud Phlu Canal community, one of the historic canal communities along the Chao Praya River. In a research paper ${ }^{8}$, Tantinipankul (2014) sets out that present-day residents of the area are descendants of Chinese merchants and low-ranking bureaucrats who served the ruling class of Bangkok before modern development and that the area is under pressure from urban infrastructure developments. The research highlights the social meaning and identity of Talad Phlu community. It reveals the historic site is an integral part of the original settlement of Bangkok's canal communities reflecting living history of petty bureaucrats, 


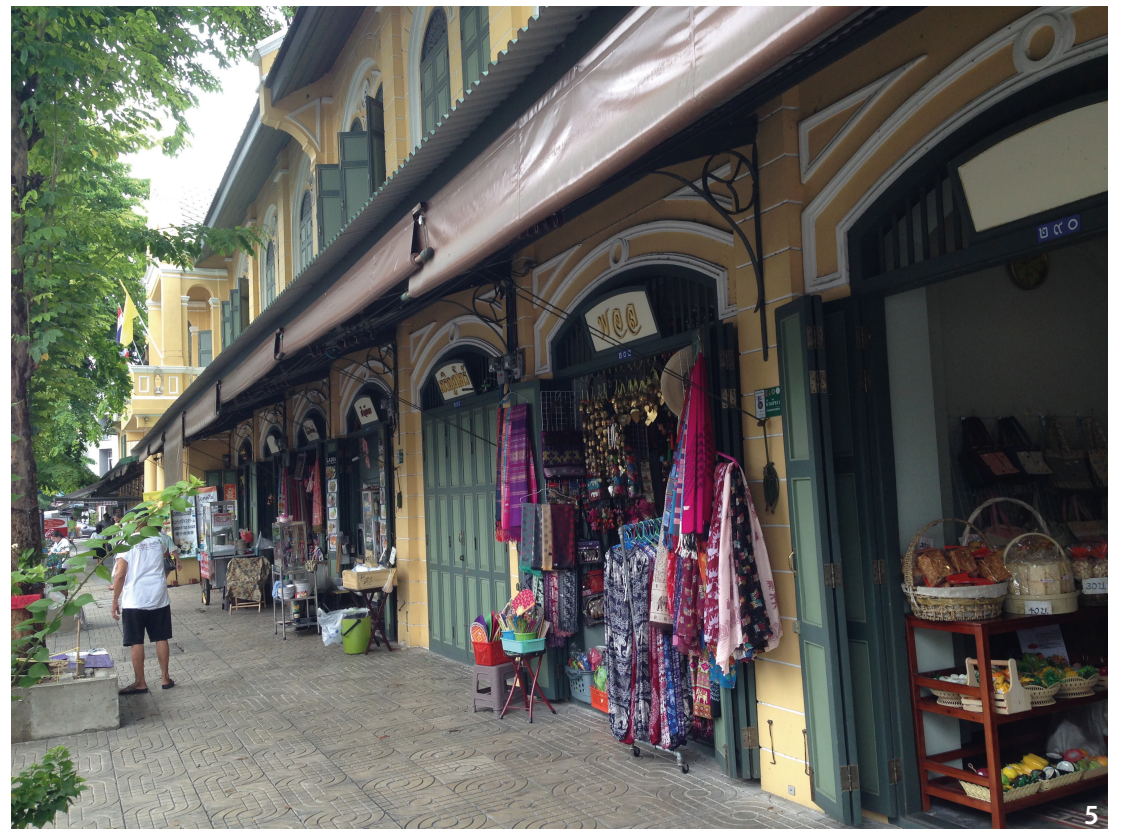

Figure 5 Tha Tien after restoration (Source: the author). merchants and labourers from the perspective of different ethnic groups (Thai, Chinese, Mon, Muslim, Malay). The outcome is an inquiry into whether it is feasible to revive such a community through various cultural heritage tourism opportunities and networks involving such activities as cycling and walking routes, as well as improvements to canal transport safety and use with involvement of the Bangkok Metropolitan Authority (BMA) Office of Cultural, Sports and Tourism Promotion. It is acknowledged nevertheless that such an approach could trigger threats of deterioration of urban fabric and/or commodification of historic places as artefacts for global consumption disconnecting them from continuity and dynamics of community. Key to avoiding such an outcome is the imperative of appreciating the community's learning process and effects of change and extent of change.

Critical to this process is addressing what are acceptable levels of change in the context of historic, natural and cultural resources. Crucial here is (a) ensuring that the business of tourism does not overwhelm community core values, ways of life and main occupations and (b) facilitating collaboration between local government and community. Such collaboration is facilitated through cultural and participatory mapping which documents heritage resources, meanings and values. In this way cultural mapping can help 'to understand the notion of local distinctiveness [and] can be a tool to help local communities have their voice heard through their involvement in the mapping process' (Taylor 2013b, 50).

\section{Ballarat, Australia}

Ballarat with a population of 101,588 , a figure expected to double, is a major regional town in the state of Victoria some $107 \mathrm{~km}$ west of Melbourne. It came to predominance in the Gold Rush era as a boom town and from that has distinctive character, morphology and sense of community with, inter alia, grand and vernacular $19^{\text {th }}$ century buildings, fine streetscapes and street trees and a clear interrelationship with its rural setting much loved by its inhabitants. The HUL experiment being applied in Ballarat's planning addresses what are often seen as diametrically opposed discourses: urban development and management of cultural heritage. In the case of Ballarat, it is particularly interesting in that it encompasses the whole town and its landscape setting engaging the local communities and it is being adopted at the local government level.

It was decided by Ballarat Council to apply the HUL approach in 2012 and join Shanghai based WHITRAP's program to implement UNESCO's HUL approach. Early work involved community-based cultural cognitive mapping exercises involving various groups to establish community views on the sense of place of the city as a whole. Stage 1 was 'Mapping Ballarat's Historic Urban Landscape ${ }^{9}$ which aimed to explore what HUL could mean in practice and in this specific locality' (Buckley et al. 2016, 101). This meant experimenting with local application in the HUL at that time consisted very much of statements and aspirations and development of an action plan in a collaborative exercise between Council Officers and consultants. 
In 2013 a long term strategy 'Today, Tomorrow, Together-the Ballarat Strategy' ${ }^{10}$ was initiated. The Council wanted to know 'What do Ballarat people value?' The Council documentation states 'Our community told us that they love Ballarat's streetscapes and street trees, sense of history, Lake Wendouree, views and settings, special places, parks and gardens, cultural experiences and sense of community.' Ballarat realises that population growth, changing economic future, overdevelopment and inappropriate development and demographic and cultural change can render heritage vulnerable. In an inspiring collaborative effort between the Council (professional staff and councillors) and the community, Ballarat is determined to ensure that conservation in the city that has resulted hitherto in a legacy of a 'rich and highly significant historic landscape and strong sense of place' will continue into the future by understanding the need 'to better target our policies, practices and tools for more inclusive and sustainable results'.

Recently a further inspiring planning document relating to Ballarat's future, Our People, Culture and Place. A Plan to Sustain Ballarat's Heritage 2017-2030 ${ }^{11}$, has been released. The document concerns an holistic approach to city planning and the future in which heritage concerns are accorded credence and recognition. It is a mature view of heritage that is not stuck in the outmoded view of heritage as a few old buildings. Rather it conforms with the current view of the pivotal role of heritage in city planning and urban renewal particular to UNESCO's Historic Urban Landscape (HUL) construct.

The commitment to heritage in Ballarat's planning is impressive. It recognises the need not merely to protect, but constructively work to sustain Ballarat's heritage. There is also reference to prioritising and celebrating elements of the city that citizens love and value. A critical word here is 'values' in that cultural heritage expressed simply is that which is inherited. In addition to tangible things and objects, significantly it includes intangible aspects of personal and collective memory, of who we are, our roots, the 'who' and 'why' of our very existence and sense of place. Cultural heritage is fundamentally about people. Notably in summarising the Ballarat HUL project Buckley et al. $(2016,106)$ point out that 'Seeing urban settlements as landscapes has had more profound impacts on the rethinking of approaches and methods than was anticipated at the start of the project for the City of Ballarat.'

\section{Summary}

Parallel with the thinking on HUL is the growing recognition of urban areas as drivers of creative industries and values associated with the notion of cultural capital
(Throsby 2010)_economics of art and culture-linked to cultural value as well as economic value. The creative industries idea is also linked to poverty alleviation, gender and youth empowerment, and sustainable use and conservation of natural resources. Petko Draganov ${ }^{12}$ suggests that considerable parts of output for creative goods and services are based on local culture where creative industries are small businesses based on traditional cultural resources operating at low investment levels. We may see therefore that links between traditional creative industries with their associated communities and the HUL approach to urban conservation in developing countries are palpable.

Both phenomena-HUL and creative industriesare closely associated with notions of heritage for which Throsby (2010) posits there are two values: economic value and cultural value. Economic value is measured in money terms whilst cultural value is multifaceted with no single unit of account. Throsby further argues that economic value deals with tangibles whether it is a use or non-use value. Cultural value involves intangibles such as symbolic meaning, social and spiritual values, historic values, authenticity. Within the realm of cultural value lies the idea of cultural capital where tangible and intangible assets have economic and cultural value. This suggests that within the realm of cultural industries thinking and in the associated heritage field, economic values should not be privileged over cultural values. How this is negotiated with the agency-local government-that invariably drives urban planning in tandem with economic concerns of trying to balance budgets is difficult to say the least. Related to this point as cogently examined by González Martínez (2017) is the issue of urban heritage authenticity and whose values are we, or should we, be addressing?

In relation to the creative city idea and what he suggests is a devaluing of heritage authenticity by a focus on tourist experiences, González Martínez highlights examples in the historic Hongkou District of Shanghai where industrial buildings from a former era have been transformed into a touristic shopping/restaurant complex and a high tech creative park. Along with well-known lilong housing neighbourhoods marketed for visitors is this a case of 'indigenous cosmopolitan identity marketed for visitors and experiences of prospective future residents without taking into account the perspective of current residents in traditional urban heritage areas' (González Martínez 2017, 58)? The dilemma here is that change in the cultural landscape of cities in the HUL approach is an accepted process as is the concept of creative industries if, inter alia, they benefit 
local communities and enhance vitality and resilience of the historic city (Bandarin and van Oers 2012, 111). Relevant also is the notion that authenticity is not static. It is a dynamic concept accommodating changes as community values morph overtime, what Herb Stovel $(2007,28)$ aptly refers to as 'progressive authenticity'.

HUL offers a context for a much needed dialogue whereby professionals, including city planners, urban designers, heritage experts in all fields and legal instrument and government personnel (national and local) engage in interdisciplinary exchange to appreciate how layered cultural experiences influence perceptions of the urban landscape and why these are important in urban outcomes involving renewal, rehabilitation or adaptive reuse. It is important in this dialogue that planners et al. understand that the concept of urban cultural landscape heritage conservation and the reality of economic and political influences on city development and expansion are not mutually exclusive, acceding that change to city form will be inevitable.

Critical to HUL is managing this change, recognising urban heritage is of vital importance for cities because it constitutes a key resource in enhancing liveability in urban areas. It fosters economic development and social cohesion with urban heritage acting as a catalyst for socioeconomic growth treating cities as dynamic organisms (UNESCO, 2013). This is all the more relevant when engaging the relevant 2015 Sustainable Development Goals ${ }^{13}$ and the 2016 New Urban Agenda (United Nations, 2016).

\section{Notes}

1. 'Process' throughout the paper is taken to mean a series of actions or steps taken in order to achieve a particular end, i.e. methodical/systematic (OED).

2. See also https://www.routledge.com/museumandheritage/posts/612

3. United Nations Conference on Trade \& Development (UNCTAD), 'Culture vital for development progress, Deputy Secretary-General tells meeting. Hangzhou International Congress 2013, http://unctad.org/en/Pages/ AboutUs.aspx $\mathrm{H}: \backslash$ Culture, sustainability, heritage unctad_org

4. International conference on 'World Heritage and Contemporary Architecture-Managing the Historic Urban Landscape', UNESCO World Heritage Centre in cooperation with ICOMOS and the City of Vienna at the request of the World Heritage Committee, adopted at its $27^{\text {th }}$ session in 2003 .

5. http://whc.unesco.org/archive/2005/whc05-15ga-inf7e. pdf
6. Designed, evolved and associative landscapes are the three categories of landscape declared for World Heritage purposes by [see above] 1992. http://whc.unesco. org/en/culturallandscape/\#1

7. Discussed at the Expert Planning Meeting on Historic Urban Landscapes, UNESCO Paris, November 2008.

8. Research project funded by National Research Council of Thailand undertaken by School of Architecture and Design, King Mongkut University of Technology Thonburi.

9. http://www.ballarat.vic.gov.au/media/3026950/mapping_ballarat_s_historic_urban_landscape.pdf

10. More details about the strategy, see http://www.ballarat.vic.gov.au/media/2972829/bt3_16pg_fa_v2.pdf

11. More details about the plan, see https://mysay.ballarat. vic.gov.au/ballarat-heritage-plan

12. Petko Draganov, Deputy Secretary of UNCTAD (see note 3 above), made these comments at the Hangzhou UNCTAD meeting 2013.

13. More information see https://sustainabledevelopment. un.org/?menu=1300

\section{References}

Ashworth, Gregory, and Brian Graham. 2012 "Heritage and the Reconceptualization of the Postwar European City." In The Oxford Handbook of Postwar European History, edited by Dan Stone, 582-599, Oxford: Oxford University Press.

Askew, Marc. 2010. “The Magic List of Global Status: UNESCO, World Heritage and the Agencies of States." In Heritage and Globalisation, Routledge Key Issues in Cultural Heritage Series, edited by Sophia Labadi and Colin Long, 19-44. Abingdon: Routledge.

Bandarin, Francesco, and Ron van Oers. 2012. The Historic Urban Landscape: Managing Heritage in an Urban Century. Chichester: Wiley Blackwell.

Biger, Gideon. 1992. "Introduction: Ideology and Landscape." In Ideology and Landscape in Historical Perspective, edited by Alan R. H. Baker and Gideon Biger, 1-14. Cambridge: Cambridge University Press.

Buckley Kristal, Steven Cooke, and Susan Fayad. 2016. "Using the Historic Urban Landscape to Re-Imagine Ballarat. The Local Context." In Urban Heritage, Development and Sustainability: International Frameworks and Local Governance, edited by Labadi Sophia and Logan William, 93-113. Abingdon: Routledge.

Cameron, Christina, and Mechtild Rössler. 2013. Many Voices, One Vision: the Early Years of the World Heritage Convention. Farnham: Ashgate. 
Cosgrove, Dennis, E. 1984. Social Formation and Symbolic Landscape. London: Croom Helm.

Du Cros, Hilary. 2002. "Conflicting Perspectives on Marketing Hong Kong's Cultural Heritage Tourism Attractions." In Proceedings of ICOMOS $13^{\text {th }}$ General Assembly, 319-321.

Fowler, Peter. 2001. "Cultural Landscape: Dreadful Phrase, Great Concept." In The Cultural Landscape: Planning for Sustainable Partnerships between People and Place, 64-69. London: UK ICOMOS.

González Martínez, Plácido. 2017. "Urban Authenticity at Stake: A New Framework for Its Definition from the Perspective of Heritage at the Shanghai Music Valley." Cities 70: 55-64.

Greffe, Xavier. 2010 "Urban Cultural Landscapes: An Economic Approach." Working Paper 1/2010, Turin: Department of Economics, University of Turin. Accessed 15 September 2018. https://www.researchgate.net/publication/254455944_Urban_cultural_landscapes_an_ economic approach

Harrison, Rodney. 2013. Heritage: Critical Approaches. Abingdon: Routledge.

Harvey, David. 2001. "Heritage Pasts and Heritage Presents: Temporality, Meaning and the Scope of Heritage Studies." International Journal of Heritage Studies 7 (4): 319-338.

Howard, Peter. 2003. Heritage: Management, Interpretation and Identity. London: Continuum.

ICOMOS. 1994. Nara Document on Authenticity. Paris, ICOMOS.

Jackson, John Brinckerhoff. 1994. A Sense of Place, a Sense of Time. New Haven: Yale University Press.

Jacques, David. 1995. “The Rise of Cultural Landscapes.” International Journal of Heritage Studies 1 (2): 91-101.

Lewis, Peirce. 1979. "Axioms for Reading the Landscape. Some Guides to the American Scene." In The Interpretation of Ordinary Landscapes: Geographical Essays, edited by Donald W. Meining, 11-32. New York: Oxford University Press.

Logan, William. 2010. "Development in World Heritage Studies in University Education.” In World Heritage and Diversity, edited by D, Offenhöußer, W. Zimmerli, M-T Albert, 38-45. Germany: German Commission for UNESCO.

Patten, Gerald. 1991. "Cultural Landscapes: The Intent and Tenor of the Times." CRM: The Journal of Heritage Stewardship 14 (6): 1-3.

Pimonsathean, Yongtanit. 2006. "Cultural Resources Management in Historic Community inBangkok: The Tha
Tien Case.” Accessed 15 September 2018. http://www. cujucr.com/downloads/pdf_4_2006/Yongtanit\%20Pimonsathean.pdf

Plachter, Harald, and Michthild Rössler. 1995. "Cultural Landscapes: Reconnecting Culture and Nature." In Cultural Landscapes of Universal Value: Components of a Global Strategy, edited by Bernd von Droste, Harald Plachter, and MichthildRössler, 15-19. Jena: Fischer.

Poulios, Ioannis. 2014. Past in the Present: A Living Heritage Approach-Meteora, Greece. London: Ubiquity Press.

Poulios, Ioannis. 2015. “Gazing at the 'Blue Ocean', and Tapping into the Mental Models of Conservation: Reflections on the Nara+20 Document." Heritage \& Society 8 (1): 158-177.

Punekar, Anwar. 2006. "Value-led Heritage and Sustainable Development: The Case of Bijapur, India.” In Designing Sustainable Cities in the Developing World, edited by R. Zetter and G. Watson, 103-120. Aldershot: Ashgate.

Sirisrisak, Tiamsoon. 2009 "Conservation of Bangkok Old Town.” Habitat International 33 (4): 1-7.

Smith, Julian. 2010. "Marrying the Old with the New in Historic Urban Landscapes." In World Heritage Papers 27 Managing Historic Cities, edited by Ron van Oers and Haraguchi Sachiko, 45-52. Paris: UNESCO World Heritage Centre.

Stovel, Herb. 2007. "Effective Use of Authenticity and Integrity as World Heritage Qualifying Conditions." City \& Time 2 (3): 21-36.

Tantinipankul, Worrasit. 2014. "The Conservation of Thailand's Sino-Thai Mercantile Heritage: TaladPhlu Canal Community of Bangkok.” Accessed 15 September 2018. http://www.arch.kmutt.ac.th/files/research/ inter_Conference/2013/14.The\%20Conservation $\% 20$ of\%20Thailand.pdf

Taylor, Ken. 2013a. “The Challenge of the Cultural Landscape Construct and Associated Intangible Values in an Asian Context." In Asian Heritage Management: Contexts Concerns and Prospects, edited by Kapila D. Silva and Neel Kamal Chapagain, 189-211. Abingdon: Routledge.

Taylor, Ken. 2013b. “Cultural Mapping: Intangible Values and Engaging with Communities with Some Reference to Asia." The Historic Environment: Policy and Practice 4 (1): 50-61.

Taylor, Ken. 2014. "Cultural Heritage Management: International Practice and Regional Applications." In Encyclopedia of Global Archaeology, Vol. 3, edited by Claire 
Smith, 1939-1951. New York: Springer.

Taylor, Ken. 2015. "Cities as Cultural Landscapes." In Reconnecting the City: The Historic Urban Landscape Approach and the Future of Urban Heritage, edited by Francesco Bandarin and Ron van Oers, 179-202. Chichester: Wiley Blackwell.

Taylor, Ken. 2017. "Landscape, Culture and Heritage: Changing Perspectives in an Asian Context." Deakin University Library, Australia. Accessed 15 September 2018. http://dro.deakin.edu.au/view/DU:30102152

Throsby, David. 2010. The Economics of Cultural Policy. Cambridge: Cambridge University Press.

UNESCO. 2011. Recommendation on the Historic Urban Landscape. Accessed 15 September 2018. http:// portal.unesco.org/en/ev.php-URL_ID=48857\&URL_ DO $=$ DO_TOPIC\&URL_SECTION $=201 . \mathrm{html}$

UNESCO. 2013. New Life for Historic Cities: The Historic Urban Landscape Approach Explained. Paris: UNESCO World Heritage Centre.

Van Oers, Ron. 2010. "Managing Cities and the Historic Urban Landscape Initiative-An Introduction." In UNESCO World Heritage Papers 27 Managing Historic Cities, edited by Ron van Oers and S. Haraguchi, 7-17. Paris: UNESCO World Heritage Centre.

Wijesuriya, Gamini, Jane Thompson, and Christopher Young. 2013. Managing World Cultural Heritage. Paris: UNESCO World Heritage Centre in association with ICCROM, ICOMOS and IUCN.

Winter, Tim. 2014. "Beyond Eurocentrism? Heritage Conservation and the Politics of Difference." International Journal of Heritage Studies 20 (2): 123-137. 